\title{
The Labour Market Impacts of the COVID-19: A Global Perspective
}

\author{
Sangheon Lee ${ }^{1} \cdot$ Dorothea Schmidt-Klau $^{1} \cdot$ Sher Verick ${ }^{1}$ \\ Published online: 6 October 2020 \\ (c) Indian Society of Labour Economics 2020
}

\section{Introduction}

The COVID-19 pandemic caused a global health crisis, which has rapidly transformed into economic and labour market shocks that have, in turn, led to a global job crisis with unprecedented magnitude. This note offers a brief overview of the current job crisis, drawing on the latest work of the ILO.

As the pandemic continues to evolve with little sign of light at the end of the tunnel, any assessment of labour market disruptions involves a high level of uncertainty. Projecting possible future trajectories of development is even more uncertain. Nonetheless, it is crucial to monitor and analyse labour market impacts with best possible data and methods and update them on a regular basis, hence helping countries develop timely and informed policy responses.

\subsection{Learning from the Great Recession (2008-2009)}

One important premise for our analysis is the rather unsuccessful experience from the Great Recession (2008-09). The mainstream policy response at the time was largely characterized by "trickledown recovery" measures, which resulted in slow economic recovery and greater social and political uncertainty.

Recovery in employment and labour income was even slower and more painful (Fig. 1), which, in turn, contributed to a further slowing down of the economic recovery and depressing productivity growth. It took more than a decade for global unemployment to return to the pre-crisis level, while youth unemployment has never managed to recover fully from the crisis. In a sense, economy and employment became disconnected. Similarly, while labour productivity continued

\footnotetext{
This note draws on the ILO Monitor: COVID-19 and the world of work, which has been published in five editions since early March 2020. All editions are available at: https://www.ilo.org/global/topics/ coronavirus/impacts-and-responses/WCMS_749399/lang--en/index.htm.
}

Sangheon Lee

lees@ilo.org

1 International Labour Organization, Geneva, Switzerland 

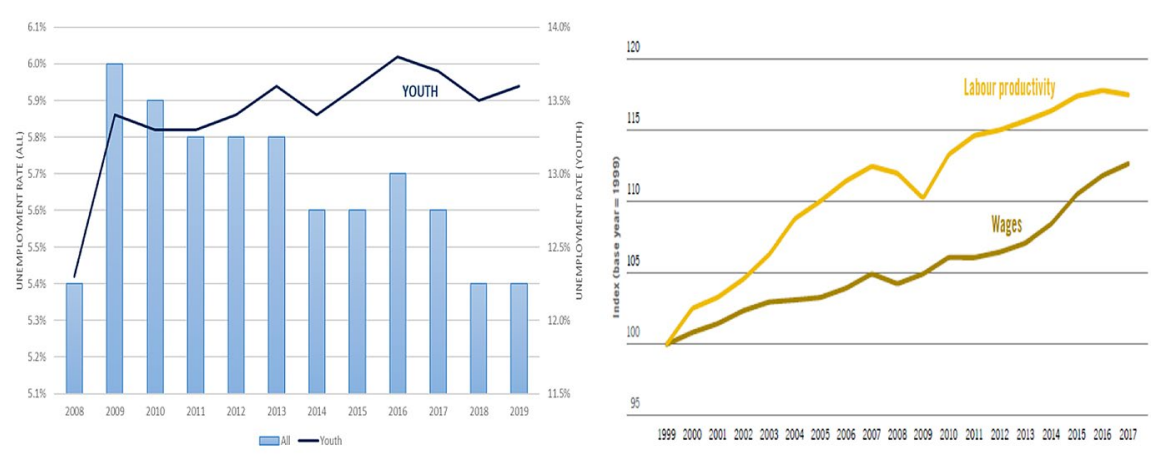

Fig. 1 Slow and painful recovery in employment and wages during the Great Recession Source: ILO

to grow, wages and labour income lagged behind. As a result, inequality remains high or, in some case, is even growing. This is why this crisis response was widely understood to represent the failure of "trickledown economics". Such mistakes should not be repeated in the current job crisis.

\subsection{Unprecedented scale of labour market disruption}

Then, what is the overall magnitude of labour market disruption? In the beginning, we used our standard modelling to predict annual average unemployment in 2020 (in terms of levels and rates). But it soon became clear that looking at "annual" and "unemployment" is insufficient, and in some cases, can be even misleading. Annual averages do not reflect realities as the situation is changing rapidly. Unemployment does not indicate the actual scale of disruption for workers, as many people keep jobs but are not working (therefore they are counted as being employed) or lost their work but do not search for jobs (therefore they are counted as inactive) or are working shorter hours (therefore counted as employed again). This means we need a shorter time horizon (e.g. month or quarter) with focus on working hours rather than employment. This is why we decided to introduce an approach based on nowcasting, which takes full advantage of high-frequency data.

Figures 2 and 3 show our latest estimates. Let us just look at the current quarter. Initially, we estimated around $7 \%$ losses in working hours but within a month, we increased them to $14 \%$. These losses include all different outcomes: inactivity, unemployment, temporary suspension of work, shorter hours. These working hour losses are equivalent to 400 million full-time jobs (assuming 48-hour working week). All regions saw two-digit losses, with the largest reduction in the Americas.

While this unprecedented scale of labour market disruption affects almost all individuals and countries, the impacts have been disproportionate, particularly making certain segments of the workforce even more vulnerable. To demonstrate this point, we briefly review the situation for informal workers, youth and women. 


\begin{tabular}{|c|c|c|}
\hline & 1st quarter 2020 & 2nd quarter 2020 \\
\hline \multirow[t]{2}{*}{ World } & $5.4 \%$ & $14.0 \%$ \\
\hline & 1st quarter 2020 & 2nd quarter 2020 \\
\hline Low-income countries & $2.4 \%$ & $11.1 \%$ \\
\hline Lower-middle-income countries & $3.0 \%$ & $16.1 \%$ \\
\hline Upper-middle-income countries & $9.3 \%$ & $12.6 \%$ \\
\hline \multirow[t]{2}{*}{ High-income countries } & $2.5 \%$ & $13.9 \%$ \\
\hline & 1st quarter 2020 & 2nd quarter 2020 \\
\hline Africa & $2.4 \%$ & $12.1 \%$ \\
\hline Americas & $3.0 \%$ & $18.3 \%$ \\
\hline Arab States & $3.1 \%$ & $13.2 \%$ \\
\hline Asia and the Pacific & $7.1 \%$ & $13.5 \%$ \\
\hline Europe and Central Asia & $3.4 \%$ & $13.9 \%$ \\
\hline
\end{tabular}

Fig. 2 Working-hour losses, world and by income group Source: ILO Monitor (5th edition)

\begin{tabular}{|c|c|c|}
\hline & $\begin{array}{l}\text { Median earnings of informal workers } \\
\text { pre COVID-19 (2016 PPP\$) }\end{array}$ & $\begin{array}{l}\text { Expected median earnings of informal workers } \\
\text { in the first month of the crisis ( } 2016 \text { PPP\$) }\end{array}$ \\
\hline World & 894 & 359 \\
\hline By income group & $\begin{array}{l}\text { Median earnings of informal workers } \\
\text { pre COVID-19 (2016 PPP\$) }\end{array}$ & $\begin{array}{l}\text { Expected median earnings of informal workers } \\
\text { in the first month of the crisis ( } 2016 \text { PPP\$) }\end{array}$ \\
\hline High-income countries & 1834 & 445 \\
\hline Upper-middle-income countries & 497 & 359 \\
\hline Lower-middle and low-income countries & 479 & 88 \\
\hline By region & $\begin{array}{l}\text { Median earnings of informal workers } \\
\text { pre COVID-19 (2016 PPP\$) }\end{array}$ & $\begin{array}{l}\text { Expected median earnings of informal workers } \\
\text { in the first month of the crisis ( } 2016 \text { PPP\$) }\end{array}$ \\
\hline Africa & 518 & 96 \\
\hline Americas & 1298 & 244 \\
\hline Asia and the Pacific & 549 & 430 \\
\hline Europe and Central Asia & 1253 & 387 \\
\hline \multicolumn{3}{|c|}{$\begin{array}{l}\text { Note: Estimates are based on weighted averages from } 64 \text { countries with data collected on a time interval between } \\
2016 \text { to } 2019 \text {. Earnings include earnings from own-account workers, employers self-reported earnings and wages of wage employees. } \\
\text { The estimates exclude unpaid family workers who are not usually asked to declare monetary earnings. Whenever possible, estimates } \\
\text { include earnings from jobs other than the main job. The original local currency values have been converted to constant } 2016 \text { PPP } \\
\text { dollars. The countries covered represent } 65 \text { per cent of the world's employees and include the economies with the largest population } \\
\text { in each region. No data is available for Arab economies. }\end{array}$} \\
\hline
\end{tabular}

Fig. 3 Potential impacts of the pandemic on earnings of informal workers Source: ILO Monitor (3rd edition)

\subsection{Workers in the informal economy at new and higher risks}

The global workforce is currently around 3.3 billion, of which around 2 billion workers (or 62 per cent) are engaged in the informal economy. Women and migrant workers are particularly vulnerable. Out of this 2 billion, almost 1.6 billion are estimated to be significantly impacted by the crisis, due to lockdown measures or because of working in high-risk sectors.

Impacts on income and poverty for informal workers are massive. We expected that the income of informal workers will decline in the first month of the crisis by 60 per cent globally. In Africa and the Americas, the drop is even over 80 per cent. 
Globally, we estimated that the COVID-19 pandemic will push relative poverty levels among informal workers from 26 to 59 per cent. And in some regions it will be much higher -80 percent or more.

These massive income effects have much to do with the nature of the pandemic. It is well known that informality is often seen as a "last-resort" option for survival, but this option has often ceased to be viable due to lockdown measures that restrict movement and economic activities. This resulted in income risks for informal workers that is much higher during this pandemic compared to previous global crises of comparable scale.

\subsection{Youth employment: “Lockdown” generation?}

Youth were vulnerable going into this crisis. Unemployment affected 67.6 million young women and men around the world or 13.6 per cent of the youth labour force. Many more millions were not in employment, education or training. More than three quarters of young people were employed in the informal economy making them extremely vulnerable to this downturn.

Against this backdrop, the COVID-19 crisis is severely impacting young people in three ways: (1) disruptions to education, training and work-based learning; (2) increased difficulties for jobseekers and new labour market entrants; and (3) job and income losses, along with deteriorating quality of employment.

At the onset of the crisis, 178 million youth were employed in sectors, such as accommodation and food services and retail trade, which have been hard hit, leading to cuts in working hours, layoffs and severe losses in incomes. According to the Global Survey on Youth and COVID-19 implemented by the ILO and other partners, more than 1 in 6 young people surveyed have stopped working since the start of the crisis (Fig. 4).

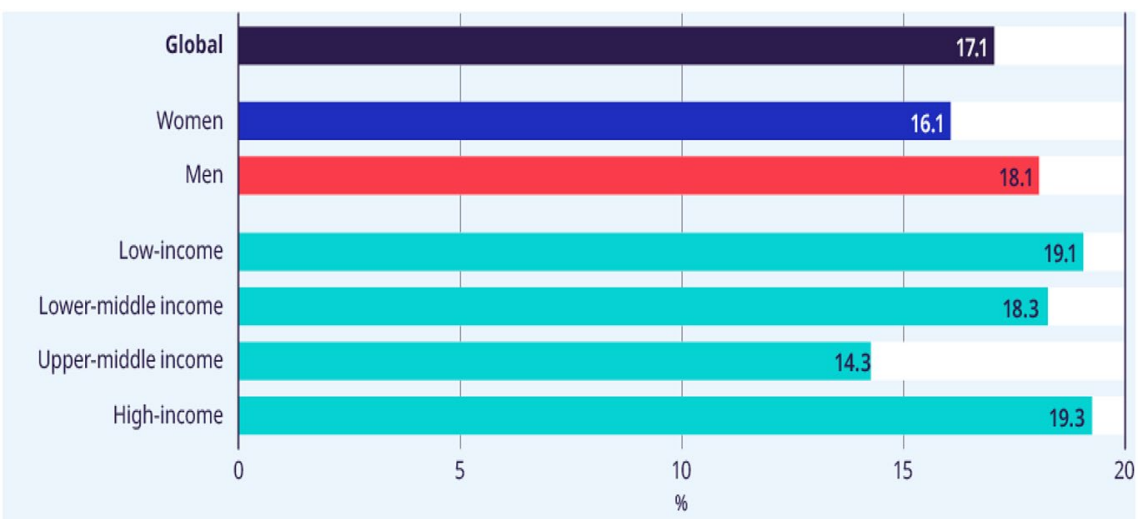

Note: The figure shows the share of young people who reported having stopped working since the start of the COVID-19 outbreak relative to all those who had worked before the outbreak.

Fig. 4 Young people (aged 18-29) who reported having stopped working after the onset of the pandemic (\%) Source: Global Survey on Youth and COVID-19; ILO Monitor (4th edition) 


\subsection{Gender inequalities being exacerbated}

Despite some progress over previous decades, gender gaps were still considerable and persistent in labour markets around the world before the onset of the COVID-19 crisis (including gaps in labour force participation, wages and quality of employment). In the light of these pre-crisis gender inequalities, the COVID-19 crisis is disproportionately affecting women workers in four main ways.

First, almost 510 million or 40 per cent of all employed women around the world work in hard-hit sectors (compared with 36.6 per cent of employed men). Second, 55 million or 72.3 per cent of domestic workers around the world were at significant risk of losing their jobs and incomes due to the lockdown and the lack of effective social security coverage. Third, women represent more than 70 per cent of those employed in health and social work. Though these women represent the bulk of frontline workers who face the direct risks of responding to the virus, they tend to be engaged in lowerskilled and lower-paid jobs in this sector. Finally, closures of early childhood education centres, care services and schools, along with the unavailability of older relatives to provide support, have exacerbated the unequal distribution of care.

\subsection{Outlook and policy challenges}

Hopes that the pandemic and its social and economic impact will fade away in the second half of 2020 will clearly not materialize with infection numbers increasing (again) in many countries, forcing governments to continuously, at least partially, lock-down workplaces. And despite the unprecedented financial interventions from governments, many enterprises and jobs will be lost for good. The lasting damage inflicted on labour markets and the difficult global economic conditions that will prevail indicate the need to maintain high levels of support to sustain recovery, in a context of unprecedented fiscal and monetary conditions. Such continuous government support needs to be fast, at large scale and targeted to those hardest hit. Premature fiscal consolidation, such as that which followed the financial crisis of 2008-09, would risk further destabilizing already weak labour markets.

The world will emerge from this pandemic with higher levels of unemployment, inequality, poverty, debt and political frustration. This makes it all the more important that, individually and collectively, governments make the ambition of "building back better" as opposed to building back to where we previously were. In many cases, social dialogue-bringing together governments, employers and workers-has proved its worth in shaping effective, balanced and acceptable policy responses. It can likewise help to shape sustainable recovery paths in the period ahead. The ILO Centenary Declaration sets out a human-centred agenda for the future of work involving investment in people's capabilities, the institutions of work and the sustainable jobs of the future, which provides important reference points for tackling the key challenges that lie ahead.

Publisher's Note Springer Nature remains neutral with regard to jurisdictional claims in published maps and institutional affiliations. 